\title{
PENINGKATAN KEMANDIRIAN ANAK MELALUI METODE PEMBELAJARAN BERBASIS MASALAH (Penelitian Tindakan Kelas Pada Kelompok A PAUD Anak Bangsa Kota Serang Provinsi Banten, Tahun Ajaran 2017/208)
}

\author{
Suryadi
}

\author{
Email: Suryadi.hikman@gmail.com
}

\begin{abstract}
The purpose of this study is to determine the increase in the independence of children through problem-based learning methods. This research is a classroom action research using a research model put forward by Kurt Lewin which was conducted in 2 (two) cycles consisting of 4 (four) meetings each. The research subjects were a group of children from the PAUD Anak Bangsa City of Serang, amounting to 10 students. Data analysis uses quantitative and qualitative. Quantitative analysis with descriptive statistics are presented in the form of tables and graphs, namely seeing the results obtained from the data of cycle I and Cycle II. Qualitative data using the Miles Huberman technique with the method of observation, interviews and documentation, then analyzed through the stages of data reduction, data presentation, and drawing conclusions. The results showed an increase in the independence of children after being given an intervention using the problem-based learning method.
\end{abstract}

Keywords: Early Childhood, Independence, Problem Based Learning Method

\begin{abstract}
Abstrak: Tujuan Penelitian ini adalah untuk mengetahui peningkatan kemendirian anak melalui metode pembelajaran berbasis masalah. Penelitian ini merupakan penelitian tindakan kelas menggunakan model penelitian yang dikemukakan oleh Kurt Lewin yang dilakukan sebanyak 2 (dua) siklus yang terdiri dari masingmasing 4 (empat) kali pertemuan. Subjek penelitian adalah kelompok A PAUD Anak Bangsa Kota Serang yang berjumlah 10 orang siswa. Analisis data menggunakan kuantitatif dan kualitatif. Analisis kuantitatif dengan statistik deskriptif yang disajikan dalam bentuk tabel dan grafik yaitu melihat hasil yang diperoleh dari data siklus I dan Siklus II. Data kualitatif dengan menggunakan teknik Miles Huberman dengan metode pengamatan, wawancara dan dokumentasi, kemudian dianalisis melalui tahap reduksi data, penyajian data, dan penarikan kesimpulan. Hasil penelitian menunjukkan adanya peningkatan kemandirian anak setelah diberikan intervensi dengan menggunakan metode pembelajaran berbasis masalah.
\end{abstract}

Kata Kunci: Anak Usia Dini, Kemandirian, Metode pembelajaran Berbasis Masalah

\section{PENDAHULUAN}

Pendidikan merupakan modal dasar untuk menyiapkan insan yang berkualitas. Menurut Undang-Undang Sisdiknas, pendidikan adalah usaha sadar dan terencana untuk mewujudkan suasana belajar dan proses pembelajaran agar peserta didik secara aktif mengembangkan potensi dirinya untuk memiliki kekuatan spiritual keagamaan, pengendalian diri, kepribadian, kecerdasan, akhlak mulia, serta keterampilan yang diperlukan dirinya, masyarakat, bangsa dan negara. Menurut UNESCO, pendidikan hendaknya dibangun dengan empat pilar, yaitu: learning to know, learning to do, learning to be, dan learning to live together (UNESCO: Pilar Pendidikan). 
Usia 4-5 tahun merupakan usia peka, dimana anak sangat sensitive untuk menerima rangsangan bagi pengembangan pribadi anak. Pada masa ini fisik dan psikis siap menerima respon stimulasi yang diberikan oleh lingkungan. Masa ini merupakan masa yang tepat untuk meletakkan dasar pertama bagi pengembangan kemampuan fisik motorik, kognitif, bahasa, sosial emosional, dan agama dan moral. Oleh sebab itu dibutuhkan kondisi dan stimulasi yang sesuai dengan kebutuhan anak agar pertumbuhan dan perkembangan anak tercapai secara optimal.

Kemandirian bukanlah keterampilan yang muncul tiba-tiba tetapi perlu diajarkan pada anak usia dini, apabila anak tidak belajar mandiri sejak usia dini akan sangat memungkinkan anak merasa bingung bahkan tidak tahu bagaimana harus membantu dirinya sendiri. Fakta yang terjadi di kelompok A PAUD Anak Bangsa Kota Serang yang berjumlah 10 anak menunjukkan bahwa kemandirian anak dalam melakukan kegiatan masih sangat rendah dan masih perlu ditingkatkan, hal ini tergambar dari prilaku anak dalam melakukan kegiatan disekolah.

Sikap kurang mandiri juga terjadi karena guru masih kurang tepat dalam menyampaikan pembelajaran, metode yang digunakan membuat anak cepat bosan dan kurang antusias dalam mengikuti pembelajaran dikelas. Dalam menyampaikan materi pembelajaran pada anak usia dini, seyogyanya seorang guru dituntut untuk lebih kreatif dalam menciptakan ide tentang model maupun metode pembelajaran yang menarik bagi anak sesuai dengan usianya dan tahapan perkembangannya.

Untuk meningkatkan kemandirian anak, salah satu metode yang bisa diterapkan adalah metode pembelajaran berbasis masalah karena dapat memotivasi siswa untuk belajar sehingga pada akhirnya dapat meningkatkan kemandiriannya. Pembelajaran Berbasis Masalah merupakan inovasi dalam pembelajaran karena dalam Pembelajaran Berbasis Masalah kemampuan berpikir siswa betul-betul dioptimalisasikan melalui proses kerja kelompok atau tim yang sistematis sehingga dapat memberdayakan, mengasah, menguji dan mengembangkan kemampuan berpikirnya secara berkesinambungan (Rusman, 2012: 229)

\section{KEMANDIRIAN ANAK USIA DINI}

Salah satu sikap yang muncul dari kematangan dalam aspek perkembangan emosional adalah kemandirian. Kemandirian merupakan hal yang penting dalam 
perjalanan hidup manusia. Perkembangan kemandirian yang dibangun sejak usia dini dapat bermanfaat hingga anak dewasa nanti. Ini dikarenakan karena kemandirian merupakan perilaku yang harus diperoleh setiap individu agar tidak bergantung pada orang lain. Kemandirian adalah kemampuan untuk mengerjakan tugas sendiri, menjaga diri sendiri, dan memulai proyek tanpa harus selalu diberi berupa yang harus dilakukan (Morrison, 2009: 228)

Anak membutuhkan kebebasan untuk mencoba melakukan sesuatunya sendiri dalam upaya membangun kemandiriannya. Hal ini sejalan dengan pernyataan Uno bahwa kemandirian yaitu kemampuan untuk mengarahkan diri mengendalikan diri, berdiri dengan kaki sendiri. Secara lebih luas, kemandirian adalah kemampuan untuk mengarahkan dan mengendalikan diri sendiri dalam berpikir dan bertindak, serta tidak merasa tergantung pada orang lain secara emosional (Uno, 2011: 77-78). Hal ini mempertegas bahwa mandiri juga dapat membantu anak untuk belajar akan rasa tanggung jawab. Ketika anak mampu untuk memilih sendiri apa yang ingin ia lakukan saat itu juga anak belajar untuk bertanggung jawab atas pilihannya.
Anak yang mandiri adalah anak yang memiliki rasa percaya diri yang tinggi. Sebagaimana Mastari menjelaskan bahwa mandiri itu merujuk pada percaya diri yang orang punyai dalam sumber-sumber yang ada pada dirinya untuk berhadapan dengan situasi apa saja (Mastari, 2011: 94). Anak yang mandiri mampu melakukan aktivitasnya sendiri, tidak bergantung pada orang lain dalam memenuhi kebutuhan emosional mereka. Anak yang diberikan kesempatan untuk melakukan sesuatu sendiri akan merasa bahwa dirinya dipercaya mampu melakukan hal tersebut dengan baik.

Anak yang mandiri adalah anak yang memiliki inisiatif yang tinggi, dimana ia mampu mengambil pilihan dan menerima konsekuensi atas pilihannya tersebut. Kemandirian sebagai kemampuan untuk mengambil pilihan dan menerima konsekuensi yang menyertainya. Kemandirian kepada anak-anak terwujud jika mereka menggunakan pikirannya sendiri dalam mengambil berbagai keputusan, dari memilih perlengkapan belajar yang ingin digunakannya, memilih teman bermain sampai hal-hal yang relatif lebih rumit dan menyertakan konsekuensikonsekuensi tertentu yang lebih serius.

Karakter mandiri yang dimiliki oleh anak usia dini akan sangat bermanfaat bagi 
mereka dalam melakukan prosedur-prosedur keterampilan dan bergaul dengan orang lain. Kemandirian anak usia dini dalam melakukan prosedur-prosedur keterampilan merupakan kemampuan untuk melakukan aktivitas sederhana sehari-hari, seperti makan tanpa harus disuapi, mampu memakai kaos kaki dan baju sendiri, bisa buang air kecil/besar sendiri, mampu memakai baju dan celana sendiri, dan dapat memilih mana bekal yang harus dibawanya saat belajar serta merapikan mainannya sendiri, kemandirian anak usia dini dalam bergaul terwujud pada kemampuan mereka dalam memilih teman, keberanian mereka belajar di kelas tanpa ditemani orangtua, dan mau berbagi bekal/jajan kepada temannya saat bermain.

\section{Kemandirian Anak Usia 4-5 Tahun}

Kemandirian anak usia 4-5 tahun sejatinya memang dibangun sejak rentang usia 1-3 tahun atau pada tahap otonomi versus malu dan ragu-ragu. Meskipun begitu selama anak berada dalam tahap selanjutnya atau tahap inisiatif versus rasa bersalah, kemandirian anak tetap dibangun seiring dengan perkembangannya rasa inisiatif di dalam diri anak. Hal ini sejalan dengan pernyataan yang menyebutkan bahwa anakanak dapat merasa bersalah jika mereka tidak didukung atau terhalang dari berinisiatif di bidang aktivitas dan selalu dibatasi upayanya untuk melakukan segala sesuatu sendiri (Morrison, 2009: 84). Ketika anak tidak diberikan kesempatan untuk belajar melakukan segala sesuatu sendiri secara tidak langsung anak berkembang menjadi anak yang tidak mandiri dan akan berujung pada berkembangnya rasa bersalah di dalam diri anak. Rasa bersalah yang dibiarkan berkembang terus menerus akan membuat anak merasa takut untuk mengerjakan sesuatu sendiri.

Anak usia 4-5 tahun juga sudah mampu memenuhi kebutuhannya sendiri. Pemenuhan kebutuhan diri sendiri ini dilakukan secara mandiri tanpa bantuan dari orang lain. Beberapa bentuk aktifitas pemenuhan kebutuhan diri yang seharusnya sudah dapat dilakukan oleh anak usia 4-5 tahun secara mandiri terdiri dari menggunakan pisau untuk memotong makanan, mengenakan dan melepaskan baju berkancing depan, buka-tutup celana beresleting, menalikan sepatu, mandi sendiri tanpa arahan, membersihkan diri seusai buang air kecil dan besar serta menyisir rambut (Nikita: http://tabloidnakita.com/artikel.php3?edisi=0946 $1 \&$ rubrik=prasekolah). Seluruh aktifitas ini merupakan aktifitas sehari-hari yang 
seharusnya mampu anak lakukan tanpa bantuan orang lain. Keberhasilan anak dalam penguasaan aktifitas ini akan membantunya untuk menjadi pribadi yang mandiri hingga dewasa nanti.

Berdasarkan beberapa pemaparan di atas, kemandirian anak usia 4-5 tahun ditandai dengan kemampuan anak dalam merencanakan sesuatu dengan tujuan yang jelas serta gigih dalam upaya mencapai tujuan tersebut, selain itu, anak juga memiliki keberanian, kepercayaan diri, dan rasa inisiatif dalam melakukan sesuatu. Kemandirian anak usia 4-5 tahun juga ditandai kemampuan anak dalam memenuhi kebutuhan dirinya secara mandiri, mampu menggunakan pisau untuk memotong makanan, mengenakan dan melepaskan baju baju berkancing depan, buka-tutup celana beresleting, memakai sepatu, mandi sendiri tanpa arahan, membersihkan diri seusai buang air kecil dan besar serta menyisir rambut. Selain itu anak juga mampu mencuci dan mengeringkan tangan sendiri serta makan sendiri menggunakan sendok dan garpu.

Adapun ciri-ciri kemandirian anak usia dini adalah: (1) memiliki kepercayaan kepada diri sendiri, (2) memiliki motivasi instrinsik yang tinggi, (3) mampu dan berani menentukan pilihannya sendiri, (4) kreatif dan inovatif, (5) bertanggung jawab menerima konsekuensi yang menyertai pilihannya, (6) mampu menyesuaikan diri dengan lingkungannya dan (7) tidak bergantung pada orang lain (Novan, 2013:33-35)

\section{Pembelajaran Berbasis Masalah}

Pendekatan pembelajaran berbasis masalah (PBM), memiliki sejarah panjang untuk mendukung pendidikan berbasis pengalaman. Pendekatan ini dikembangakan pada tahun 1970 di McMaster University di Canada, hingga Pendekatan pembelajaran berbasis masalah sudah merambah ke berbagai fakultas dan lembaga pendidikan didunia. Penelitian yang tertuang dalam teori psikologis berkeyakinan bahwa siswa tidak hanya belajar dari guru, melainkan siswa juga dapat bejalar dari berbagai pengalaman yang telah dialami untuk menyelesaikan suatu masalah, pembelajaran berbasis masalah merupakan Pendekatan pembelajaran yang menekankan pada siswa untuk belajar melalui penyelesaian masalah yang difasilitasi oleh guru. Siswa bekerja dalam suatu kelompok untuk mengidentifikasi yang diperlukan dalam memecahkan sebuah masalah, disanalah guru bertindak sebagai fasilitator dalam proses pembelajaran bukan sekedar sumber pengetahuan untuk siswa. 
Pembelajaran berbasis masalah dapat diartikan sebagai rangkaian kegiatan pembelajaran yng menekankan kepada proses penyelesaian masalah yang dihadapi secara ilmiah (Wina Sanjaya, 2008: 214) Menurut Moffit dalam Andi Prastowo mengatakan pembelajaran berbasis masalah adalah suatu pendekatan pembelajaran yang menggunakan masalah dunia nyata sebagai suatu konteks bagi siswa untuk belajar tentang berpikir kritis dan ketrampilan pemecahan masalah serta untuk memperoleh pengetahuan dan konsep yang esensi dari mata pelajaran (Prastowo, 2013: 79).

Pendapat Mofit sejalalan dengan Richard I. Arends, esensi Pembelajaran Berbasis masalah berupa menguyuhkan berbagai situasi bermasalah yang autentik dan bermakna kepada siswa, yang dapat berfungsi sebagai batu loncatan untuk investigasi dan penyelidikan dalam prakteknya pembelajaran berbasis masalah melibatkan presentasi situasi-situasi yang autentik dan bermakna. Peran guru dalam pembelajaran berbasis masalah menyajikan berbabagi masalah autentik, mempasilitasi penyelidikan siswa, dan mendukung pembelajaran siswa. Pembelajaran berbasis masalah tidak mungkin terjadi kecuali jika guru menciptakan lingkungan kelas sebagai tempat perrtukaran ide-ide terbuka dan jujur dapat terjadi. (Richard, 2008: 41)

Tujuan pembelajaran berbasis masalah adalah untuk membantu peserta didik mengembangkan pengetahuan fleksibel yang dapat diterapkan dibanyak situasi yang berlawanan dengan inner knowledge. Sedangkan Anita Woolfolk mengatakan tujuan pembelajaran berbasis masalah adalah meningkatkan motivasi instrinsik dan keterampilan dalam memecahkan masalah, kalaborasi, dan belajar seumur hidup (Martinis, 2013:64).

Pembelajaran berbasis masalah dapat diterapkan bila didukung dengan lingkungan bejar yang konstuktivistik. Lingkungan belajar yang konstuktivistik mencakup beberapa faktor menurut Jonassen dalam Regeluluth dalam martinis yamin, dengan demikian pembelajaran berbasis masalah: 1) Menciptakan pembelajaran yang bermakna, dimana peserta didik dapat memecahkan masalah yang mereka hadapi dengan cara mereka sendiri sesuai dengan pengetahuan dan pengalamannya, kemudian menerapkan dalam kehidupan nyata, 2) dapat mengintegrasikan pengatahuan dan keterampilan secara stimulan dan mengaplikasikannya secara relevan, 3) dapat meningkatkan kemampuan berpikir kritis menumbuhkan insiatif peserta didik dalam 
bekerja, memotivasi internal untuk belajar dan dapat mengembangkan hubungan intrapersonal dalam bekerja kelompok (Martinis, 2013: 63).

Pembelajaran based learning mengharuskan siswa untuk melakukan investigasi autentik dan berusaha menemukan solusi riil untuk masalah riil, siswa harus menganalisa dan menetapkan masalah, membuat hipotesis dan membuat prediksi, mengumpulkan dan menganalisis informasi, melaksanakan eksperimen (bila memungkinkan), membuat infrensi, dan menarik kesimpulan (Richard, 2008: 42).

Guru seharusnya juga menuntut siswa untuk mendapatkan cara atau strategi dalam memecahkan masalah, dengan memulai penalaran yang mendalam dan mengarahkan siswa untuk berpikir meta kognitif dan kritis, olehnya dari itu guru memediasi siswa dalam proses mendapatkan informasi, misalnya memediasi siswa untuk mencari sumber, setelah mendapatkan sumber guru mengarahkan siswa untuk menghubungkan antar satu sumber dengan sumber lain, sehingga siswa betul-betul paham dan mengerti tentang apa yang dipelajari. Proses ini sejalan dengan Tan dalam Taufik Amir mengatakan fokus pendidik dalam Pembelajaran berbasis masalah diantanya: sebagai fasilitator, menuntut atau mengarahkan dan memediasi siswa selama proses pembelajaran berlangsung (Taufik, 2013: 21).

Berdasarkan beberapa pendapat diatas maka dapat disimpulkan pembelajaran berbasis masalah lahir berdasarkan kepada psikologi kognitif yang mengatakan bahwa belajar adalah proses perubahan tingkah laku karena adanya pengalaman, karena pembelajaran berbasis masalah membuat siswa berpikir, menyelesaikan masalah, dan guru hanya sebagai fasilitator bagi siswa.

\section{METODE}

Penelitian ini digunakan metode penelitian tindakan Kelas untuk mendapatkan hasil yang akurat, alur penelitian tindakan ini mengacu pada model penelitian tindakan yang dikemukakan oleh Kurt Lewin. Kurt Lewin menggambarkan action research sebagai suatu spiral langkah-langkah, yang masing-masing langkah mempunyai 4 tahap, yaitu: (1) planning, (2) Acting, (3) Observing, (4) Reflecting.

\section{HASIL DAN PEMBAHASAN}

Peneliti melakukan penilaian siklus 1 pada 3 aspek kemandirian anak, diantaranya yaitu: 1) Kemampuan untuk menentukan pilihan, 2) bertanggung jawab menerima 
konsekuensi yang menyertai pilihannya dan 3) kemampuan mengendalikan emosi.

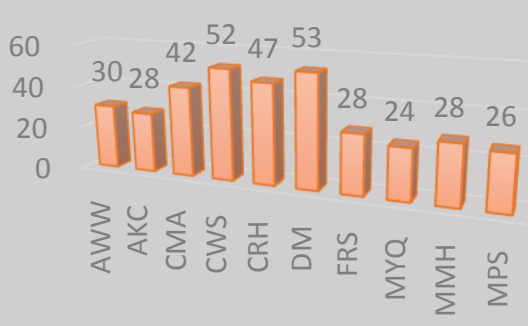

Grafik 4.1 Kemandirian Anak pada siklus I di Kelompok A PAUD Anak Bangsa Kota Serang Tahun Ajaran 2017/2018

Berdasarkan data pada grafik di atas, maka dapat dideskripsikan bahwa kemandirian anak kelompok A masih pada kategori berkembang. Skor tertinggi sebesar 52 hanya dicapai oleh satu anak dan skor terendah sebesar 24 .

Data yang diperoleh dari siklus I Dengan rata-rata 35,8 dalam kategori berkembang. Berdasarkan besarnya TCP yang telah ditetapkan oleh peneliti bersama dengan kolaborator yaitu sebesar 38 maka hanya terdapat 5 atau $50 \%$ anak masih menunjukkan sikap belum mandiri, dan 50\% telah menunjukkan kemandiriannya. Hal ini menjadi panduan bagi peneliti dan kolaborator untuk melaksanakan tindakan yang lebih baik pada siklus selanjutnya yaitu siklus II.
Peneliti melakukan penilaian siklus II pada 3 aspek kemandirian anak, diantaranya yaitu: 1) Kemampuan untuk menentukan pilihan, 2) bertanggung jawab menerima konsekuensi yang menyertai pilihannya dan 3) kemampuan mengendalikan emosi.

\section{Название диаграммы}

100

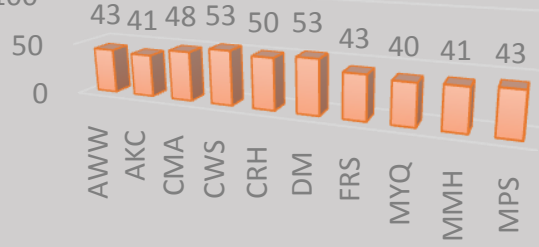

Grafik 4.2 Kemandirian Anak pada siklus II di Kelompok A PAUD Anak Bangsa Kota Serang Tahun Ajaran 2017/2018

Berdasarkan data pada grafik di atas, maka dapat dideskripsikan bahwa kemandirian anak kelompok A berada pada kategori Berkembang Sesuai Harapan (BSH). Skor tertinggi sebesar 52 hanya dicapai oleh satu anak dan skor terendah sebesar 40 .

Data yang diperoleh dari siklus II Dengan rata-rata 45,8 dalam kategori berkembang sesuai harapan. Berdasarkan besarnya TCP yang telah ditetapkan oleh peneliti bersama dengan kolaborator yaitu 
sebesar 38 maka terdapat 7 anak sikap berkembang sesuai harapan dan 3 anak yang mulai berkambang sikap mandiri, Sehingga $75 \% \%$ telah menunjukkan kemandiriannya. Pada tabel siklus 1 hingga siklus II rata-rata TCP kelas terus meningkat secara signifikan. Sehingga dapat disimpulkan bahwa kemampuan anak dalam kemandirian pada kelompok A PAUD Anak Bangsa Kota Serang pada siklus II berada pada persentase 75\%. Jadi dapat dikatakan sudah mencapai kriteria keberhasilan $71 \%$ yang telah ditetapkan sehingga tidak perlu dilakukan tindakan selanjutnya.

\section{PEMBAHASAN.}

Hasil analisis data kuantitatif yang diperoleh adalah data awal menunjukkan rata-rata TCP kelas dari kemandirian anak kelompok A PAUD Anak Bangsa pada siklus 1 adalah sebesar 35,8. Selanjutnya pada siklus II mengalami peningkatan sebesar 9,83 menjadi 45,5. Dengan demikian peningkatan yang diperoleh anak dari pra siklus sampai dengan siklus II adalah sebesar 9.8.

Kemandirian anak ditunjukkan pada saat anak berada disekolah dengan melihat beberapa indikator yang telah dideskripsikan oleh peneliti diantaranya pada saat anak datang kesekolah, yaitu sebesar 18 butir pernyataan yaitu: membuka sepatu, meletakkan tas, berbaris, memilih alat tulis yang akan digunakan, merapikan kembali alat yang sudah digunakan, menyelesaikan tugas yang diberikan guru, mencuci tangan sebelum makan, membuka bekal makan, makan sendiri, membagi makanan, menutup bekal makanan, mencuci tangan setelah makan, membersihkan sisa makanan, bermain bersama, masuk kembali ke dalam kelas, menjawab pertanyaan yang diajukan oleh guru dan keluar kelas.

Kegiatan pembelajaran dengan metode pembelajaran berbasis masalah dilakukan guru guna membuat anak tanpa sadar dan tanpa paksaan akan menerapkan sikap mandiri terutama pada butir penyataan yang telah ditentukan oleh peneliti. Dengan melalui cerita anak akan menerapkan sikap tersebut dalam kehidupan sehari-hari anak, gurupun menerapkan metode pendukung lainnya dalam meningkatkan kemandirian anak diantaranya dengan menerapkan metode pembiasaan, metode pendampingan serta reward. Guru selalu memantau setiap aktivitas yang anak lakukan, sehingga pada saat guru menemukan anak kesulitan dalam melakukan aktivitasnya guru bisa memberikan motivasi dan bantuan sekadarnya sehingga anak akan berusaha mengembangkan kemandiriannya. Selain 
itu, jika guru menemukan anak yang sudah mulai menunjukkan peningkatan kemandiriannya maka guru akan memberikan reward atau hadiah, hal ini sengaja dilakukan agar anak termotivasi dalam meningkatkan kemandiriannya.

Berdasarkan pembahasan yang telah dikemukakan diatas maka dapat disimpulkan bahwa kemandirian anak dapat ditingkatkan melalui metode pembelajaran berbasis masalah. Kemandirian anak yang berkembang meliputi semua indikator dan khususnya empat indikator yang bermasalah yaitu: Indikator menyesuaikan diri dengan lingkungan, indikator bertanggung jawab atas kegiatan yang dipilih, indikator melakukan kegiatan dengan waktu yang telah ditentukan dan indikator mampu berbagi dengan teman.

\section{SIMPULAN}

Proses penerapan tindakan dengan metode pembelajaran berbasis masalah yang dilakukan dalam siklus terdiri dari 8 kali tindakan. Proses kegiatan ini menyeluruh pada setiap tindakannya terdiri dari: a) kegiatan awal meliputi guru membangun apersepsi anak tentang tema dan tugas yang akan dilakukan hari ini, b) kegiatan inti meliputi pelaksanaan tindakan dengan metode pembelajaran berbasis masalah, dan c) kegiatan akhir meliputi tindak lanjut dari kegiatan inti.

Hasil penelitian menunjukkan adanya peningkatan kemandirian anak dengan metode pembelajaran berbasis masalah. Adapun peningkatan hasil pengamatan siklus I rata-rata skor TCP sebesar 35,8 dan siklus II yaitu skor sebesar 45,8, total peningkatan sampai dengan siklus II sebesar 10,00. Penelitian ini mencapai target $71 \%$.

Bila ingin meningkatkan kemandirian anak maka salah satu cara adalah dengan menggunakan metode pembelajaran barbasis masalah

\section{SARAN}

Bagi guru, dapat memperoleh pengetahuan tentang metode pembelajaran berbasis masalah dan peningkatan kemandirian serta disarankan untuk melakukan perbaikan yang berkelanjutan agar proses peningkatan kemandirian dapat diterapkan secara efektif, berdaya guna dan berhasil guna;

Bagi sekolah, diharapkan hasil penelitian ini dapat menjadi acuan, memberikan masukan yang berarti dan bermakna mengenai penerapan metode pembelajaran berbasis masalah terhadap peningkatan kemandirian serta disarankan agar dapat mengembangkan metode pembelajaran berbasis masalah dengan 
PERNIK Jurnal PAUD, VOL 2 NO.1 April 2019

kegiatan pelatihan dan pendampingan yang dilakukan secara terencana dan berkelanjutan sesuai dengan kebutuhan anak usia dini.

Bagi orang tua, diharapkan dapat menjadi salah satu media bagi orang tua dalam peningkatan kemandirian anak usia

\section{DAFTAR PUSTAKA}

Amir Taufik. 2013, Inovasi Pendidikan Melalui Problem Based Learning, Bagaimana Pendidik Memberdayakan Pemelajar di Era Pengetahuan. Jakarta: Kencana

Arends I Richard, 2008. Learning to Teach Jilad II. Yogyakarta: Pustaka Belajar

Mastari Mohamad. 2011. Nilai Karakter: Refleksi Untuk Pendidikan Karakter. Yogyakarta: LaksBang PRESSindo

Morrison S George S.2009. Dasar- dasar Pendidikan Anak Usia Dini. Jakarta: Indeks

Nakita, Kemandirian Anak Prasekolah (http://tabloidnakita.com/artikel.php3?edisi=0946 $1 \&$ rubrik=prasekolah) diakses pada tanggal 21 November 2015 pukul 23.11 WIB.

Pilar Pendidikan, Empat Pilar Pendidikan yang direkomendasikan UNESCO yang dapat digunakan sebagai Prinsip Pembelajaran yang bisa dini dan dapat menjadikan sarana komunikasi yang efektif serta saling membangun kedekatan antara keduanya.

Bagi peneliti selanjutnya, diharapkan dapat memperkaya kajian-kajian penelitian terkait dengan peningkatan kemandirian melalui metode yang bervariasi

diterapkan di dunia Pendidikan. Google untuk http://haneef4h.multiply.com/journ al/item/48 19:45 PM, 01 November 2015 .

Rusman,2012. Model-model Pembelajaran Mengembangkan Profesionalisme Guru. Jakarta: Rajawali Pers.

Sanjaya Wina, 2008. Strategi Pembelajaran Berorientasi Standar Proses Pendidikan Jakarta: Prenada Media

Uno B Hamzah,2011. Orientasi Baru Dalam Psikologi Pembelajaran. Jakarta: Bumi Aksara,

Wiyani Ardy Novan, 2013. Bina Karakter Anak Usia Dini. Yogyakarta: ArRuzz Media.

Yamin Martinis,2013. Strategi dan Metode dalam Pendekatan Pembelajaran. Jakarta: GP Pers Group 2013 